\title{
Effect of Supplementing Moringa (Moringa Oleifera) Leaves Meal to Quail Diets on Productive Performance
}

Oday k. Hamad ${ }^{1}$, Gaafar M. El- Gendi ${ }^{2}$, Osama H. El-Garhy ${ }^{3 *}$ and Tareq K. Aljumaili ${ }^{4}$

1,2,3 Animal Production Department, Faculty of Agriculture, Benha University, Egypt

4 Animal Production Department, Faculty of Agriculture, Tikrit University, Iraq

* Corresponding author: osama.elsayed1977@yahoo.com

\begin{abstract}
This study was conducted to investigate the effect of dietary supplementation of $M$. oleifera leaves meal (MOLM) as natural growth promoter on the productive performance of quail birds. A total number of 180 unsexed one week old Japanese quail chicks with nearly similar initial average weight were used in this study. Chicks were randomly distributed into four experimental groups each of 45 birds in 3 replicates each of 15 birds. Chicks of the $1^{\text {st }}$ experimental group were fed on the basal diet (without additives) and considered as the control group. Chicks of the $2^{\text {nd }}, 3^{\text {rd }}$ and $4^{\text {th }}$ experimental groups were fed the basal diets supplemented with MOLM at levels of 3, 6 and $9 \mathrm{~g} / \mathrm{kg}$ diet, respectively. Results obtained revealed significant variation $(\mathrm{p}<0.05)$ in averages of body weight (LBW), body weight gain (BWG), growth rate (GR), feed conversion (FC), carcass traits, mortality rate and relative economical efficiency (REE). The highest significant improvements in LBW, BWG, GR, FC, PI, carcass traits, REE and lower mortality rate were observed in the group of chicks that fed on diet supplemented with MOLM at a level of $6 \mathrm{~g} / \mathrm{kg}$ diet, followed by those fed diet supplemented with MOLM $3 \mathrm{~g} / \mathrm{kg}$ diet by then those fed diet supplemented with $9 \mathrm{~g} / \mathrm{kg}$ diet. However, chicks fed control diet showed lower averages of LBW, BWG, GR, FC, PI, carcass traits and higher mortality rate. From the economical point of view, it could be recommended to use MOLM at a level of 6 and $3 \mathrm{~g} / \mathrm{kg}$ diet, respectively to improve the productive performance and economical efficiency of quails.
\end{abstract}

Keywords: Quails, Moringa, growth performance, economical efficiency.

\section{Introduction}

In recent years, the looking for alternatives growth promoters instead of antibiotics to use in animal and poultry production field becomes one of strategic world goals. Thus, this change has stimulated the researchers to look for an alternative supplement such as the medicinal plants or their essential oils (Williams and Losa, 2002; Lee et al., 2003 and Hernandez et al., 2004). The medicinal plants and their essential oil are characterized by several effects, including antimicrobial activity (Giannenas $\boldsymbol{e t} \boldsymbol{a l}$., 2003 and Lee et al., 2004) antioxidant activity (Basmacioğlu, et al., 2004 and Giannenas et al., 2005) and led to improved poultry and animal performance.

Moringa oleifera leaves are reported to have potential prebiotic effects and potentially antioxidant phytochemicals, such as chlorogenic acid and caffeic acid (Siddhuraju and Becker, 2003). M. oleifera leaf meal contains $27.51 \%$ crude protein, $19.25 \%$ crude fiber, $22.3 \%$ ether extract, $7.13 \%$ ash and $76.53 \%$ dry matter (Oduro et al., 2008). The Moringa oleifera leaf meal, widely available in many tropical countries, is also a good source of antioxidant compounds such as ascorbic acid, flavonoids, phenolics and carotenoids (Teixeira et al., 2014). The underlying effects of the bioactive compounds in $M$. oleifera leaves are not clear. However, it could be inducing prebiotic effects, bacterial and immunestimulant activities which resulting in increased productivity of broiler chicks. In addition, $M$. oleiferai leaf meal (MOLM) extract has affected of on growth performance and carcass characteristics of broiler chickens. A few studies were carried out to study the effect of feeding on diets supplemented with MOLM on quail productivity of quail birds. For this reasons, the aim of this work was to investigate the effect of inclusion different levels of $M$. oleifera leaves meal (MOLM) in quail diets on production performance of quails. The response of the previous feeding treatment was measured as growth performance, feed intake and conversion, carcass yield, mortality rate, economical efficiency of quails.

\section{Materials and Methods}

The present study was carried out at the Poultry Farm, Department of Animal resource, College of Agriculture, Tikrit University the Republic of Iraq during the period from $19^{\text {th }}$ of September to the $30^{\text {th }}$ of October, 2017. The biochemical parameters, meat quality and microbiological studies were conducted at the laboratories belong to the same university.

\section{Experimental design}

A total number of 180 one week old unsexed Japanese quail of nearly similar live body weight were chosen randomly and distributed into seven experimental groups each of 45 chicks in three replicates (15 chicks/each). The average live body weight of chicks of different treatments at the start of the experiment ranged between 33.55 and $34.44 \mathrm{~g}$ 
without significant differences. The experimental design used in this study includes four experimental treatments, the control group was fed the basal diet without any supplementation (treatment1), and birds of the $2^{\text {nd }}, 3^{\text {rd }}$ and $4^{\text {th }}$ treatments were fed the basal diet supplemented with Moringa oleifera leaves powder at a level of 3,6 and $9 \mathrm{~g} / \mathrm{kg}$ diet, respectively. Birds of all experimental groups were fed on basal diet (contained about 3000 kilo calorie, kcal, metabolizable energy, ME, and $24 \%$ crude protein, $\mathrm{CP}$ ) during the first seven days post hatching, before it has distributed into the different experimental treatments. The natural growth promoter was used to substitute the total feed mixture of the control diet mainly yellow corn. Feed and water were provided adlibitum during all the experimental period.
Housing and Management of Experimental birds

Chicks of all experimental treatments were kept under similar management, hygienic and environmental conditions. Wood shaving was used at $10 \mathrm{~cm}$ depth as a litter. Artificial lighting was provided over the 23 hours daily during the whole experimental period. Floor brooders with gas heaters were used to provide chicks with heat needed for brooding. Brooding temperature was maintained at $37^{\circ} \mathrm{C}$ during for the first 5 days of chick's age then decreased by $2{ }^{\circ} \mathrm{C}$ weekly until the end of brooding period. Chicks were vaccinated against Newcastle disease. No drugs or antibiotics were used in this experiment against diseases. Feed and water were provided ad-libitum throughout all the experimental period. The basal diet (Table 1) was formulated according to the recommended requirement of NRC, (1994).

Table 1. Composition and calculated analysis of the basal diet

\begin{tabular}{ll}
\hline Ingredients & Control (basal) diet \\
\hline Yellow corn & 56.00 \\
Soybeans meal (44\%) & 27.90 \\
Corn gluten (60\%) & 12.00 \\
di-calcium phosphate & 1.70 \\
Calcium carbonate & 1.35 \\
Salt & 0.25 \\
Broiler premix* & 0.30 \\
DL. methionine & 0.20 \\
Lysine & 0.30 \\
Total & 100.00 \\
\hline Calculated analysis** & 2948.3 \\
ME(kcal/kg) & 24.39 \\
CP (\%) & 0.97 \\
Calcium & 0.45 \\
Available phosphorus (\%) & \\
*Each 3.0 Kg of broiler premix manufactured by Agri-Vet Company, Egypt contains : Vit. A, 12000000 IU ; Vit. D3 2000000 \\
IU ; Vit. E, 10 g; Vit. K3, 2.0 g; Vit. B1, 1.0 g; Vit. B2, 5 g; Vit. B6, 1.5 g; Vit. B12,10 mg; choline chloride, $250 \mathrm{~g}$; biotin, \\
50 mg ; folic acid, 1 g ; nicotinic acid, 30 g; Ca pantothenate, 10 g; Zn, 50 g ; Cu,10 g; Fe, 30 g ; Co, 100 mg ; Se, 100 mg \\
; I, 1 g ; Mn, 60 g and anti-oxidant, 10 g, and complete to 3.0 Kg by calcium carbonate. \\
** According to NRC, (1994)
\end{tabular}

\section{Data Collection and Estimated Traits}

\section{Live Body Weight, Body Gain and Growth Rate:}

The live body weight (LBW) was obtained by weighing the birds individually to the nearest gram in the early morning before receiving any feed and water through the experimental period $\left(1^{\text {st }}, 4^{\text {th }}\right.$ and $6^{\text {th }}$ weeks of age). Individual LBW were totaled and divided by the number of checks to obtain the average LBW.

Average live body weight gain (BWG) was calculated by subtracting the average initial LBW of a certain period from the average final LBW of the same period. Weight gains and growth rate were calculated according to the following formulas suggested by Broody, (1949). Weight gain $=\mathrm{W} 2-\mathrm{W} 1$, Growth rate $\%=(\mathrm{W} 2-\mathrm{W} 1 /(\mathrm{W} 2+\mathrm{W} 1) / 2) \times 100$, whereas; $\mathrm{W} 1$ and $\mathrm{W} 2$ are individual body weights at the two successive periods

\section{Feed Intake and Conversion:}

Daily feed intake (FI) per chick was calculated every 7 days interval for each group and sub-group as follows: Average FI / bird / day = Weekly feed intake / bird's number $\times 7$

Feed conversion (FC) was calculated as the amount of feed required for producing a unit of gain according to the following formula:

$\mathrm{FC}=($ Average FI / chick / week / Average BWG / chick / week)

\section{Slaughter and carcass traits}

Slaughter test was performed at the end of the experimental period (6 weeks). Five birds from each experimental treatment (with the nearest average weight to each treatment) were randomly chosen. The assigned birds were deprived of feed for 16 hours prior to slaughter, thereafter they were individually weighed to the nearest gram (pre-slaughter weight), slaughtered according to recommended Islamic 
tradition method by cutting the throat and jugular vein near the first neck vertebra with a sharp knife. After complete bleeding, each bird was dipped in a water bath for two minutes and feathers were removed by hand. Shanks and head were separated, the birds were then eviscerated and intestine, gizzard, lungs, spleen, liver, heart and reproductive organs were removed. The carcass (included the front part with wings and the hind part) and giblets (empty gizzard, liver and heart) were separately weighed. The giblets weight did not include spleen weight in quails because it is very small (about $0.1 \mathrm{~g}$ ).

The proportional weights of carcass, giblets and total edible parts to pre-slaughter weight were calculated as following:-

1- Carcass $\%=($ Carcass weight/pre-slaughter weight $)$ $\times 100$

2- Giblets weight $\%=($ Giblets weight $/$ pre-slaughter weight $) \times 100$

3- Total edible parts $\%=$ Carcass weight + giblets weight/pre-slaughter weight $\times 100$

\section{Mortality Rate}

The accumulative mortality rate $\%$ was obtained by adding the number of dead birds during the experimental periods and divided by the total number of chicks at the beginning of the experiment.

\section{Performance index}

The performance index (PI) of the whole period of the experiment was calculated according to the equation described by North, (1981) as follows; PI = LBW $(\mathrm{kg}) / \mathrm{FC} \times 100$.

\section{Economical Efficiency}

The economic efficiency (EEf) was calculated according to the cost of one-kg feed (included the price of feed additives) and the prices of one $\mathrm{kg}$ body gain during the same time of experiment. The values of EEf were calculated as the net revenue per unit of total cost. Relative EEf was calculated assuming that the EEf of the control $=100$.

\section{Statistical Analysis}

Analysis of variance was calculated on all data obtained using the general Linear Models Procedures (SAS, 2004). Significant differences between treatments means were determined using Duncan's New Multiple-Rang test (Duncan, 1955).

The statistical analysis for studied traits was carried out according to the following linear model:

$\mathrm{X}_{\mathrm{ij}}=\mu+\mathrm{T}_{\mathrm{i}}+\mathrm{e}_{\mathrm{ij}}$

Whereas:

$\mathrm{X}_{\mathrm{ij}}=$ the $\mathrm{N}^{\text {th }}$ observations

$\mu=$ the overall mean

$\mathrm{T}_{\mathrm{i}}=$ the effect of the $\mathrm{i}^{\mathrm{th}}$ treatments

$\mathrm{e}_{\mathrm{ij}}=$ random error assumed to be independently and randomly distributed

\section{Results and Discussion}

Live body weight, weight gain and growth rate

The results obtained in Table (2) revealed that the averages live body weight (LBW), weight gain (BWG) and growth rate (GR) at the end of the experiment $\left(6^{\text {th }}\right.$ week of age $)$ of quail birds fed diets supplemented with Moringa oleifera leaves meal (MOLM) at level of $6 \mathrm{~g} / \mathrm{kg}$ diet showed significantly $(\mathrm{P}<0.001)$ higher averages of LBW, BWG and GR (229.33 g, 194.41g and $147.13 \%$, respectively), followed by those fed diet supplemented with $3 \mathrm{~g} / \mathrm{kg}$ diet $(207.92 \mathrm{~g}, 172.96$ and $142.43 \%$, respectively), then by those fed diet supplemented with $9 \mathrm{~g} / \mathrm{kg}$ diet (202.86g, 167.86 and $141.13 \%$, respectively), compared to the birds of control group which recorded the lower averages $(186.56 \mathrm{~g}, 151.66$ and $136.97 \%$, respectively). The improvement in LBW, BWG and GR of quail chicks which fed on diets supplied with MOLM could be attributed to the presence of vitamin $\mathrm{C}$, vitamin $\mathrm{E}$, carotenoids, flavonoids and selenium in M. oleifera leaves which make it a potential antioxidant that improved the growth performance of birds (Moyo et al., 2012).These results agreed with those reported by David et al. (2012) and Banjo (2012) who are stated that using $M$. oleifera leaves or fruit powder instead of antibiotic as a growth promoter has beneficial effects on the growth performance of broiler chicken.

Table 2. Effect of dietary M. oleifera leaves meal levels on live body weigt, weight gain and growth rate of Japanese quail of different experimental groups at the whole period of the experiment

\begin{tabular}{llll}
\hline $\begin{array}{l}\text { Level } \\
(\text { g/kg diet) }\end{array}$ & $\begin{array}{l}\text { Life body weight }(\mathbf{g}) \\
\text { at 6 wks }\end{array}$ & $\begin{array}{l}\text { Body weight gain }(\mathbf{g}) \\
\text { At 1-6 wks }\end{array}$ & $\begin{array}{l}\text { Growth rate }(\%) \\
\text { At 1-6 wks }\end{array}$ \\
\hline 0 & $186.56 \pm 0.73^{\mathrm{d}}$ & $151.66 \pm 0.7^{\mathrm{d}}$ & $136.97 \pm 0.77^{\mathrm{c}}$ \\
3 & $207.92 \pm 0.63^{\mathrm{b}}$ & $172.96 \pm 0.59^{\mathrm{b}}$ & $142.43 \pm 0.09^{\mathrm{b}}$ \\
6 & $229.33 \pm 0.51^{\mathrm{a}}$ & $194.41 \pm 0.43^{\mathrm{a}}$ & $147.13 \pm 0.04^{\mathrm{a}}$ \\
9 & $202.86 \pm 1.71^{\mathrm{c}}$ & $167.86 \pm 1.71^{\mathrm{c}}$ & $141.13 \pm 0.42^{\mathrm{b}}$ \\
MSE & 3.070 & 2.943 & 0.589 \\
significance & $* * *$ & $* * *$ & $* * *$ \\
\hline
\end{tabular}

Whereas; $a, b, c \& d$ : There is no significant difference $(\mathrm{P}>0.05)$ between any two means, within the same column have the same superscript letter for each treatment only.

$* * *=$ Very high significant $(\mathrm{P}<0.001)$. 


\section{Feed intake and conversion}

Data presented in Table (3) revealed that no significant variations was found in feed intake (FI) and highly significant variations $(\mathrm{P}<0.001)$ in feed conversion ratio (FC) of quail birds due to the feeding on diets supplemented with different levels of MOLM (Moringa oleifera) during the whole period of the experiment. Quail birds fed diet supplemented with MOLM at a level of $6 \mathrm{~g} / \mathrm{kg}$ diet showed higher improve in FC ( $2.59 \mathrm{~g}$ feed/g gain), followed by those fed diet supplemented with MOLM at a level of $3 \mathrm{~g}$ $/ \mathrm{kg}$ diet (2.93 $\mathrm{g}$ feed/g gain), then those fed diet supplemented with MOLM at a level of $9 \mathrm{~g} / \mathrm{kg}$ diet. However, the lower FC was observed by quail chicks that fed on control diet (3.34 g feed/g gain). These results were agree with those stated by Banjo (2012) who found no significantly differences in feed intake due to feeding on MOLM. However, Alabi et al. (2016) concluded that aqueous $M$. oleifera leaf extract included up to $90 \mathrm{ml} / \mathrm{litre}$ in the drinking water of broiler chicken reduced feed intake $(12.83 \%)$ when compared with the control. In addition, Moustafa $e t$ al. (2015) and Alabi et al. (2016) concluded that there are significant improvement in FC of chicken due to supplementation of Moringa oleifera in diets or in drinking water compared to control (nonsupplemented group). However, Banjo (2012) showed that the inclusion of four levels (i.e., $0 \%, 1 \%$, $2 \%$ and $3 \%$ ) of Moringa oleifera leaf meal didn't improve feed conversion.

Table 3. Effect of dietary M. oleifera leaves meal levels on average feed intake and feed conversion of Japanese quail of different experimental groups at the whole period of the experiment

\begin{tabular}{lll}
\hline $\begin{array}{l}\text { Level } \\
\text { (g/kg diet) }\end{array}$ & $\begin{array}{l}\text { Feed intake } \\
\text { (g/bird/day) }\end{array}$ & $\begin{array}{c}\text { Feed conversion } \\
\text { at 1-6 wks }\end{array}$ \\
\hline 0 & $14.46 \pm 0.06$ & at 1-6 w ks \\
3 & $14.48 \pm 0.08$ & $3.34 \pm 0.02^{\mathrm{a}}$ \\
6 & $14.4 \pm 0.03$ & $2.93 \pm 0.02^{\mathrm{c}}$ \\
9 & $14.47 \pm 0.02$ & $2.59 \pm 0.01^{\mathrm{d}}$ \\
MSE & 0.008 & $3.02 \pm 0.03^{\mathrm{b}}$ \\
significance & NS & 0.002 \\
\hline
\end{tabular}

Whereas; $a, b, c \& d$ : There is no significant difference $(\mathrm{P}>0.05)$ between any two means, within the same column have the same superscript letter for each treatment only.

*** $=$ Very high significant $(\mathrm{P}<0.001)$

$\mathrm{NS}=$ non-significant

\section{Mortality and Performance index $(\%)$}

The results obtained in table (4) showed that significant variations $(\mathrm{p}<0.001)$ in mortality rate (MR) and performance index (PI) of quail birds due to feeding on diets supplemented with MOLM levels. Chicks fed diets supplemented with different levels of MOLM showed lower MR and higher PI percentages compared to non-supplemented one (control). The lower average of MR was showed by chicks fed diet supplement MOLM at a level of 9 and $6 \mathrm{~g} / \mathrm{kg}$ diet $(0.00$ and $2.22 \%)$, followed by those fed diet supplemented MOLM at a level of $3 \mathrm{~g} / \mathrm{kg} \operatorname{diet}(6.67 \%)$, compared to control group which was recorded the higher average of MR $(8.89 \%)$. Concerning to, the effect of MOLM levels on PI of quail birds, it is clearly observed that birds fed diet supplemented with MOLM at a level of $6 \mathrm{~g} / \mathrm{kg}$ diet showed the higher PI mounted $(8.85 \%)$, followed by those fed diet supplemented with MOLM at a level of $3 \mathrm{~g} / \mathrm{kg}$ diet mounted $(7.10 \%)$, then by those received MOLM at a level of $9 \mathrm{~g} / \mathrm{kg}$ diet that intermediated value of PI $(6.73 \%)$. However, the lower value of PI was recorded by control group (5.59\%). The previous results showed decreasing in average mortality rate due to feeding on diets supplemented with MOLM levels may be attributed to the antimicrobial activities against some pathogenic microorganisms in gastrointestinal tract and immune responses that resulted in improve the health case of birds and low mortality consequently and performance index as well. these results agree with those reported with Moyo et al., (2012) and Donkor et al., (2013) who stated that Moringa leaves has a potential antioxidant (vitamin $\mathrm{C}$, vitamin $\mathrm{E}$, carotenoids, flavonoids and selenium), In addition, Gaia (2005) reported that Moringa (Moringa oleifera) leaves has anti-bacterial anti- fungal activities, it seems to reduce the activity of pathogenic bacteria and molds and improves the digestibility of chicken. Thus, they are concluded that applying Moringa leaves decreased mortality rate of chicken. Further to, AbdelMalak et al. (1995); Abdel-Azeem (2002) and Abdel-Latif et al. (2002 and 2004) reported that broilers and Japanese quails fed on diets supplemented with herbs and medicinal plants improved PI values compared to the control ones. 
Table 4. Effect of dietary M. oleifera leaves meal levels on mortality and performance index (\%) of Japanese quail of different experimental groups at the end of the experiment

\begin{tabular}{lll}
\hline Level (g/kg diet) & $\begin{array}{l}\text { Mortality (\%) } \\
\text { during (1-6 wks) }\end{array}$ & $\begin{array}{l}\text { Performance index (\%) } \\
\text { during (1-6 wks) }\end{array}$ \\
\hline 0 & $8.89 \pm 0.00^{\mathrm{a}}$ & $5.59 \pm 0.06^{\mathrm{d}}$ \\
3 & $6.67 \pm 0.00^{\mathrm{b}}$ & $7.10 \pm 0.07^{\mathrm{b}}$ \\
6 & $2.22 \pm 2.22^{\mathrm{c}}$ & $8.85 \pm 0.05^{\mathrm{a}}$ \\
9 & $0 \pm 0.00^{\mathrm{c}}$ & $6.73 \pm 0.13^{\mathrm{c}}$ \\
MSE & 0.707 & 0.020 \\
significance & $* * *$ & $* * *$ \\
\hline
\end{tabular}

Whereas; $a, b, c \& d$ : There is no significant difference $(\mathrm{P}>0.05)$ between any two means, within the same column have the same superscript letter for each treatment only.

*** $=$ Very high significant $(\mathrm{P}<0.001)$

\section{Carcass traits}

The results showed in table (5) revealed that significant variations $(\mathrm{P}<0.05)$ were found in total edible meat percentage due to feeding on diets supplemented with Moringa (Moringa oleifera). Quail chicks fed diets supplemented with $M$. oleifera at level of 6 and $3 \mathrm{~g} / \mathrm{kg}$ diet showed the highest significant relative weights of carcass $(67.62$ and $67.27 \%$, respectively) and total edible parts (72.69 and $72.11 \%$, respectively) compared to the other treatment applied and control group. It could be concluded that the improving in carcass traits of quails fed different levels of Moringa (Moringa oleifera) may be attributed to their beneficial effect on feed utilization as previously mentioned which lead to the improve in growth performance and consequently improved carcass traits.
These results agree with those reported by Narimani-Rad et al., (2011) who reported that broilers fed on diet with medical plants such as a mix of $1 \%$ oregano with $0.5 \%$ ziziphora plus $0.5 \%$ peppermint has significant $(\mathrm{P}<0.05)$ effect on some carcass characterization and carcass yield of broiler chicks compared to the control. On the other hand, Sarica et al., (2009) found no differences $(\mathrm{P}>0.05)$ in hot and cold carcass yield of quail birds at 35 -d-old fed on diets supplemented with oregano essential oil $(1 \mathrm{~g} / \mathrm{kg})$, cinnamon $(1 \mathrm{~g} / \mathrm{kg})$ and the mixture of them $(0.5 \mathrm{~g} / \mathrm{kg}$ from each). Also, Rahimi et al., (2011) showed that feeding broiler chickens on mix of thyme $0.1 \%$, coneflower $0.1 \%$ and garlic $0.1 \%$ had no significant effect on relative weights of the carcass, abdominal fat pad, and digestive organs.

Table 5. Effect of dietary $M$. oleifera leaves meal levels on carcass traits of Japanese quail of different experimental groups at the end of the experiment

\begin{tabular}{|c|c|c|c|c|c|c|c|}
\hline \multirow{2}{*}{$\begin{array}{l}\text { Level } \\
\text { (g/kg diet) }\end{array}$} & \multirow{2}{*}{$\begin{array}{l}\text { LBW } \\
\text { (g) }\end{array}$} & \multicolumn{2}{|l|}{ Carcass } & \multicolumn{2}{|c|}{ Giblets } & \multicolumn{2}{|c|}{ Total edible meat } \\
\hline & & (g) & $(\%)$ & (g) & $(\%)$ & (g) & $(\%)$ \\
\hline 0 & $\begin{array}{l}184.1 \\
\pm 0.49\end{array}$ & 119.00 & $\begin{array}{l}64.66 \\
\pm 0.69^{\mathrm{b}}\end{array}$ & 8.60 & $\begin{array}{l}4.66 \\
\pm 0.15\end{array}$ & 127.60 & $\begin{array}{l}69.32 \\
\pm 0.55^{\mathrm{b}}\end{array}$ \\
\hline 3 & $\begin{array}{l}207.93 \\
\pm 0.62\end{array}$ & 139.90 & $\begin{array}{l}67.27 \\
\pm 1.30 \mathrm{a}\end{array}$ & 10.10 & $\begin{array}{l}4.83 \\
\pm 0.19\end{array}$ & 149.90 & $\begin{array}{l}72.11 \\
\pm 1.29^{\mathrm{a}}\end{array}$ \\
\hline 6 & $\begin{array}{l}229.33 \\
\pm 0.52\end{array}$ & 155.10 & $\begin{array}{l}67.62 \\
\pm 0.01^{\mathrm{a}}\end{array}$ & 11.60 & $\begin{array}{l}5.07 \\
\pm 0.02\end{array}$ & 166.70 & $\begin{array}{l}72.69 \\
\pm 0.02^{\mathrm{a}}\end{array}$ \\
\hline 9 & $\begin{array}{l}201.43 \\
\pm 0.72\end{array}$ & 132.80 & $\begin{array}{l}65.92 \\
\pm 0.08^{\mathrm{ab}}\end{array}$ & 9.80 & $\begin{array}{l}4.86 \\
\pm 0.04\end{array}$ & 142.60 & $\begin{array}{l}70.78 \\
\pm 0.04^{\mathrm{ab}}\end{array}$ \\
\hline
\end{tabular}

Whereas; a \& b: There is no significant difference $(\mathrm{P}>0.05)$ between any two means, within the same column have the same superscript letter for each treatment only.

$* * *=$ Very high significant $(\mathrm{P}<0.001)$.

\section{Economical efficiency}

Results in Table (6) revealed that the highest relative economic efficiency (REE) was observed with quail chicks fed diet supplemented with MOLM at a level of $6 \mathrm{~g} / \mathrm{kg}$ diet mounted (120.02\%), followed by those fed diet supplemented with $3 \mathrm{~g} / \mathrm{kg}$ diets being (110.67\%) compared with control group (100.0\%). However, chicks fed diet supplemented with MOLM at a level of $9 \mathrm{~g} / \mathrm{kg}$ diet recorded the lower REE $(86.08 \%)$. These results are going in the same trend with the previous trend mentioned in growth performance and FC traits in this study. This result might be attributed to the improving in growth performance and the low cost of MOLM that lead to increase the REE. 
Table 6. Effect of dietary M. oleifera leaves meal levels on relative economical efficiency (REE) of Japanese quail of different experimental groups at the end of the experiment

\begin{tabular}{llllllll}
\hline & \multicolumn{6}{c}{ Relative economical efficiency } \\
\cline { 2 - 7 } $\begin{array}{l}\text { Level } \\
\text { (g/kg diet) }\end{array}$ & $\begin{array}{l}\text { Average } \\
\text { gain } \\
\text { (kg) }\end{array}$ & $\begin{array}{l}\text { Total } \\
\text { revenue/ } \\
\text { kg gain } \\
\text { (US\$) }\end{array}$ & $\begin{array}{l}\text { Total } \\
\text { feed } \\
\text { intake/ } \\
\text { chick's g }\end{array}$ & $\begin{array}{l}\text { Total feed } \\
\text { cost/chick } \\
\text { (US\$) }\end{array}$ & $\begin{array}{l}\text { Net } \\
\text { revenue } \\
\text { chick/ } \\
\text { (US\$) }\end{array}$ & $\begin{array}{l}\text { Economical } \\
\text { efficiency } \\
\text { (EE) }\end{array}$ & REE \\
\hline 0 & 151.66 & 0.91 & 506.25 & 0.30 & 0.61 & 203.3 & 100.00 \\
3 & 172.96 & 1.04 & 506.89 & 0.32 & 0.72 & 225.0 & 110.67 \\
6 & 194.41 & 1.17 & 503.79 & 0.34 & 0.83 & 244.1 & 120.02 \\
9 & 167.86 & 1.01 & 506.32 & 0.36 & 0.65 & 173.0 & 86.08 \\
\hline
\end{tabular}

Net revenue chick (US\$) = Total revenue/ kg gain (US\$) - Total feed cost/ chick (US\$)

$\mathrm{EEf}=$ Net revenue /chick (US\$)/ Total feed cost/ chick (US\$)

Price of $1 \mathrm{~g} \mathrm{BWG}=0.60$ cent

Price of $1 \mathrm{~g}$ Moringa $=0.014$ US\$

Price of $1 \mathrm{~g}$ feed $=0.0006$ US\$

\section{References}

Abd El-Latif, S.A.; Ahmed, F.A. and El-Kaiaty, A.M. (2002): Effect of feeding dietary thyme, black cumin, dianthus and fennel on productive and some metabolic responses of growing Japanese quail. Egypt. Poult. Sci., 22: 109-125.

Abd El-Latif, S.A.; El-Yamany, A.T. and El-Daly, E.A.F. (2004): Evaluation of using different sources of medicinal herbs in growing Japanese quail diets. Egypt. J. Nutr. and Feeds., 7: 69-81.

Abdel-Azeem, F. (2002): Digeston, neomycin and yeast supplementation in broiler diets under Egyptian summer conditions. Egypt. Poult. Sci., 22: 235-257.

Abdel-Malak, N.Y.; Abdel-Malak, M.S.; El-Gendi, G.M. and Naguib, E.F. (1995): Effect of feeding different levels of herbal feed additives on broiler performance in relation to some metabolic functions. Egypt. Poult. Sci., 15: 111-139.

Alabi, O.J.; Malik, A.D.; Ng'ambi, J.W.; Obaje, P. and Ojo, B.K. (2016). Effect of aqueous Moringa oleifera (Lam) leaf extracts on growth performance and carcass characteristics of Hubbard broiler chicken. Brazilian J. of Poultry Science, 19(2); 273-2780.

Banjo, S. (2012). Growth and performance as affected by inclusion of Moringa oleifera leaf meal in broiler chick diet. J. Biol. Agric. Healthcare, 2(9): 35-38.

Basmacioglu, H.; Tokusoglu, O. and Ergul, M.(2004):The effect of oregano and rosemary essential oils or alpha-tocopheryl acetate on performance and lipid oxidation of meat enriched with n-3 PUFA's in broilers. S. Afr. J. Anim. Sci., 34(3):197-210

Broody, S. (1949). Biomergetic and growth. Reinhold publication ctop. New York, NY.

David, L.S.; Vidanarachchi, J.K.; Samarasinghe, K.; Cyril, H.W. and Dematawewa, C.M.B. (2012). Effects of moringa based feed additives on the growth performance and carcass quality of broiler chicken. Tropical Agricultural Research. 24 (1): 12-20.

Donkor, R.L., Glover, K., Addae, D. and Kubi, K.A. (2013). Estimating the nutritional value of the leaves of Moringa oleifera on poultry. Food and Nutrition Sciences. 4: 1077-1083.

Duncan, D.B. (1955). Multiple ranges and multiple tests. Biometric, 11: 14.

Gaia, S. (2005). Wonder tree 100 facts moringa fact 04 exceptional animal feed moringa as livestock feed \& pet food. Moringa Mission Trust. Available at: http://gaiathelivingplanet.blogspot.com /2005/ 06/wondertree-100-facts-moringa-fact- 04. html (Accessed 31 October 2013).

Giannenas, I.; Florou-Paneri, P.; Botsoglou, N.A.; Christaki, E. and Spais, A.B. (2005): Effect of supplementing feed with oregano and/or $\alpha$ tocopheryl acetate on growth of broiler chickens and oxidative stability of meat. J. Anim. Feed Sci., 14: 521-535.

Giannenas, I.; Florou-Paneri, P.; Papazahariadou, M.; Christaki, E.; Botsoglou, N.A. and Spais, A.B. (2003). Effect of dietary supplementation with oregano essential oil on performance of broilers after experimental infection with Eimeria tenella. Arch. Anim. Nutr., 57: 99-106

Hernández, F.; Madrid, J.; García, V.; Orengo, J. and Megias, M.D. (2004). Influence of two plant extracts on broilers performance, digestibility, and digestive organ size. Poult. Sci., 83: 169-174.

Lee, K.W.; Everts, H., Kappert, H.J.; Frehner, M.; Losa, R. and Beynen, A.C. (2003). Effect of dietary essential oils on growth performance, digestive enzymes and lipid metabolism in female broiler chickens. Br. Poult. Sci., 44: 450-457.

Lee, K.W.; Everts, H.; Kappert, H.J.; Van Der Kuilen J.; Lemmens, A.G.; Frehner, M. and Beynen, A.C. (2004): Growth performance, intestinal viscosity, fat digestibility and plasma cholesterol in broiler chickens fed a rye-containing diet without or with essential oil components. Int. J. Poult. Sci., 3 (9): 613-618. 
Moustafa, K.M.El.; Shata, R.F.H.; Mousa, M.A.M., Alghonimy, H.A.H. and Youssef, S.F. (2015). Effect of using Moringa oleifera leaf meal on performance of Japanese quail. Egypt. Poult. Sci., 35(IV): 1095-1108.

Moyo, B.; Oyedemi, S.; Masika, P.J. and Muchenje, V. (2012). Polyphenolic content and antioxidant properties of Moringa oleifera leaf meal extracts and enzymatic activity of liver from goats supplemented with Moringa oleifera/Sunflower cake. Meat Sci., 02:29.

Narimani-Rad, M.; Nobakht, A.; Shahryar, H.A.; Kamani, J. and Lotfi, A. (2011): Influence of dietary supplemented medicinal plants mixture (Ziziphora, Oregano and Peppermint) on performance and carcass characterization of broiler chickens. J. Med. Pl. Res., 5: 5626-5629.

North, M.O. (1981). Commercial chicken production manual. Avi publishing company. INC, West port. Connecticut, USA

NRC (1994). National Research Council. Nutrient Requirements of Poultry. National Research Council, National Academy Press, Washington, D.C., $9^{\text {th }}$ Revised Edition.

Oduro, I.; Ellis, W.O. and Owusu, D. (2008). Nutritional potential of two leaf vegetables: Moringa oleifera and impomea batatas leaves. Scientific, Research and Essay, 3(2): 57-60.
Rahimi, S.; Teymouri Zadeh, Z.; Karimi Torshizi, M.A.; Omidbaigi, R. and Rokni, H. (2011): Effect of three herbal extracts on growth performance, immune system, blood factors and intestinal selected bacterial population in broiler chickens. J. Agric. Sci. Tech., 13:527-539

Sarica, S.; Corduk, M.; Yarim, G.F.; Yenisehirli, G. and Karatas, U. (2009): Effects of novel feed additives in wheat based diets on performance, carcass and intestinal tract characteristics of quail .S. Afr. J. Anim. Sci., 39: 144-157.

SAS (2004). SAS User's Guide. Version 9.1 ed. SAS Inst. Inc., Cary, NC.

Siddhuraju, P. and Becker, K. (2003). Antioxidant properties of various solvent extracts of total phenolic constituents fro three different agroclimatic origins of drumstick tree (Moringa oleifera Lam.) leaves. J. Agricultural and Food Chemistry 51(8): 2144-2155.

Teixeira, E.M.B.; Carvalho, M.R.B.; Neves, VA. and Silva, M.A. (2014). Arantes pereira, L. cheimcal characteristics and fractionation of proteins from Moringa oleifera Lam leaves. Food Chemistry, 147: 51-54.

Williams, P. and Losa, R. (2002). The use of essential oils and their compounds in poultry nutrition. World Poult., 17: 14-15. 